\title{
Rancang Bangun Sistem Monitoring Kualitas Air untuk Pemeliharaan Organisme Laut
}

\author{
Adi Susanto $^{\# 1}$, Alimuddin ${ }^{* 2}$, Muh. Herjayanto ${ }^{\# 3}$, Weksi Budiaji ${ }^{\# 4}$, Nur Fitria ${ }^{+5}$ \\ ${ }^{\#}$ Fakultas Pertanian, Universitas Sultan Ageng Tirtayasa \\ Jl. Raya Jakarta Km. 4 Panancangan, Cipocok Jaya Kota Serang, Banten 42122 Indonesia \\ 1adisusanto@untirta.ac.id \\ 3herjayanto@untirta.ac.id \\ 4budiaji@untirta.ac.id \\ *Fakultas Teknik, Universitas Sultan Ageng Tirtayasa \\ Jl. Raya Jakarta Km. 4 Panancangan, Cipocok Jaya Kota Serang, Banten 42122 Indonesia \\ 2alimuddin@untirta.ac.id \\ ${ }^{+}$Mahasiswa Magister Teknik Elektro Universitas Brawijaya \\ Jalan M.T. Haryono 167 Malang Indonesia 65145 \\ 5nur.fitria507@gmail.com
}

\begin{abstract}
Abstrak - Kualitas air pada wadah pemeliharaan dan budidaya organisme laut merupakan aspek penting yang harus diperhatikan. Mekanisme pemeliharaan dan kontro kualitas air laut lebih kompleks dibandingkan dengan air tawar karena lebih rentan terhadap cemaran yang berasal dari sisa metabolisme atau sisa makanan. Kemajuan teknologi saat ini memungkinkan untuk melakukan manajemen kualitas air secara terkontrol sehingga lebih efisien. Pengembangan sistem monitoring kualitas air dapat dilakukan menggunakan mikrokontrol arduino yang dilengkapi dengan sensor suhu, DO (dissolved oxygen) dan salinitas. Ketiga parameter tersebut menjadi pembatas utama bagi kelangsungan hidup organisme air laut. Hasil penelitian menunjukkan bahwa sistem yang dibangun dapat bekerja baik sesuai dengan perubahan kondisi parameter pengukuran dengan tingkat kesalahan $0,8-3,8 \%$. Kebutuhan listriknya yang rendah ( 9 volt) memungkinkan variasi sumber energi yang dapat digunakan antara lain aliran listrik negara, generator, baterai, maupun sumber energi terbarukan seperti energi matahari atau energi angin. Meskipun demikian, keandalan sistem monitoring yang dibangun memerlukan validasi di lapangan sebelum diterapkan pada lingkungan yang sebenarnya.
\end{abstract}

Kata kunci - kontrol, laut, monitoring, parameter, organisme

\section{Pendahuluan}

Aktivitas penelitian, pemeliharaan dan budidaya organisme air laut membutuhkan kualitas air yang baik dan stabil. Penanganan dan pengelolaan kualitas air laut lebih kompleks bila dibandingkan dengan pengelolaan kualitas air tawar sehingga dibutuhkan sistem pemeliharaan kualitas air yang terintegrasi [1]. Salah satu tantangan dalam mengelola sistem kualitas air untuk ikan laut adalah tingginya kandungan nitrogen dalam air laut yang berasal dari sisa metabolisme dan dapat menyebabkan kematian bagi organisme [2]. Meskipun demikian, masalah tersebut dapat diatasi melalui penggunaan sistem resirkulasi yang terdiri atas reaktor down-flow hanging sponge (DHS) yang dikombinasikan dengan reaktor up-flow sludge blanket (USB). Penggunaan sistem tersebut efektif untuk menjaga kualitas air laut tetap baik, namun belum dibangun dalam suatu sistem kontrol yang terintegrasi [3].

Kemajuan teknologi telah menghasilkan berbagai alternatif untuk dapat mengendalikan kualitas air dalam lingkungan tertentu berbasis kendali mikrokontrol. Setiap peneliti menghasilkan model dan sistem yang berbeda tergantung pada jenis dan kapasitas wadah pemeliharaan yang digunakan. Arduino dapat digunakan sebagai mikro kontrol untuk mengukur DO pada tambak udang [4] dan sistem deteksi kualitas air bersih menggunakan multi sensor [5]. Penelitian [6] menggunakan mikrokontrol dengan MQTT protokol dan telpon pintar berbasis android sebagai sistem kendali kualitas air budidaya di akuarium vertikal untuk mengendalikan parameter suhu, $\mathrm{pH}$ dan DO Penelitian lainnya [7] menggunakan sensor $\mathrm{pH}$, suhu, dan DO melalui bahasa program Visual Studio 2010 dan C\#NET yang dikombinasikan dengan sistem informasi geografis untuk mengendalikan kualitas perairan budidaya karamba air tawar di China. Meskipun demikian, penelitian sebelumnya masih terfokus pada sistem monitoring kualitas air tawar atau air bersih. Penerapan sistem monitoring berbasis arduino untuk pengendalian kualitas air laut masih sangat terbatas. Hal ini antara lain disebabkan parameter indikator untuk kualitas air laut lebih banyak, harga sensor yang lebih mahal serta membutuhkan algoritma yang lebih kompleks ([3], [4]). 
Penelitian ini bertujuan untuk menghasilkan sistem monitoring kualitas air laut yang dapat digunakan pada kegiatan penelitian, pemeliharaan hingga budidaya organisme air laut. Hasil penelitian ini diharapkan menjadi alternatif teknologi tepat guna baik untuk institusi pendidikan, penelitian maupun perusahaan.

\section{Perancangan Sistem}

Rancang bangun sistem monitoring kualitas air yang dikembangkan pada penelitian ini dibagi menjadi lima tahapan utama. Tahapan rancang bangun yang dilakukan yaitu perancangan sistem, perancangan algoritma, perangkaian komponen, ujicoba sistem dan validasi kinerja sistem yang dihasilkan. Validasi dilakukan menggunakan alat standar untuk pengukuran suhu, DO dan salinitas. Parameter DO dan suhu divalidasi menggunakan Lutron DO-5510 dan salinitas divalidasi menggunakan refraktometer Atago 2382 Master 20T.

Sistem monitoring kualitas air laut dapat dibagi menjadi tiga segmen yaitu input, proses (kontrol) dan output. Struktur sistem serupa juga dikembangkan pada monitoring $\mathrm{pH}$ air untuk tambak ikan di Ponorogo [8] dan kualitas air tambak udang vaname [9]. Input pada sistem yang dikembangkan adalah sensor oksigen terlarut (DO), sensor salinitas dan sensor suhu. Pada bagian proses atau kontrol, digunakan mikrokontrol arduino mega 2560. Untuk menampilkan data pada bagian output, digunakan perekam data (logger) dan LCD display. Diagram blok perancangan sistem monitoring suhu, oksigen terlarut, dan salinitas menggunakan mikrokontroler arduino mega 2560 disajikan pada Gambar 1.

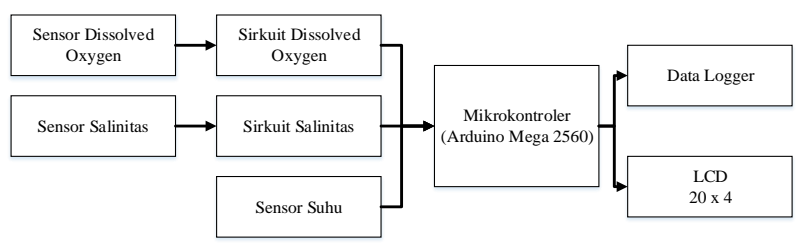

Gambar 1. Diagram blok rancang bangun sistem monitoring kualtas air

\section{A. Sensor DO}

Sensor yang digunakan untuk pengukuran oksigen terlarut adalah sensor DO dari produk DFROBOT dan memiliki kabel konektor berupa BNC seperti disajikan pada Gambar 2a. Sensor DFROBOT banyak digunakan dalam aplikasi mikrokontrol karena memiliki tingkat akurasi yang tinggi [10]. Sensor DO yang digunakan mampu mendeteksi jumlah kandungan oksigen terlarut antara 0-20 mg/l. Sensor ini memiliki sirkuit yang berisi rangkaian pengkodisian sinyal yang menghubungkan sensor dengan mikrokontroler. Rangkaian pengkodisian sinyal ini memerlukan suplai tegangan sebesar 3,3-5,0 V dan mengeluarkan sinyal sebesar 0-3 V. Papan pengkodisian sinyal ini berdimensi sebesar $42 \mathrm{~mm}$ x 32 $\mathrm{mm}$ seperti disajikan pada Gambar $2 \mathrm{~b}$.
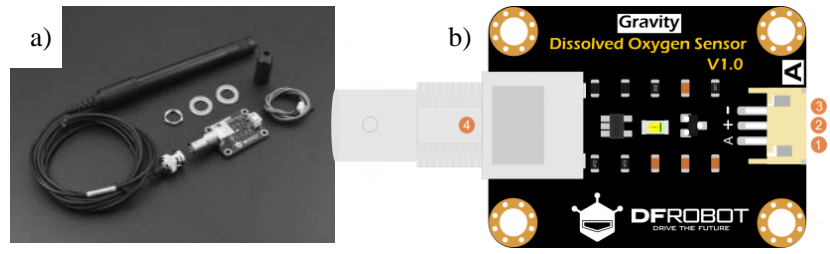

Gambar 2. Sensor dan sirkuit pengukuran kandungan oksigen terlarut

\section{B. Sensor Salinitas}

Sensor salinitas yang digunakan adalah sensor produk dari Atlas-Scientific tipe K.10 seperti disajikan pada Gambar 3a. Sensor ini memiliki akurasi pengukuran antara $10 \mu \mathrm{S} / \mathrm{cm}-1 \mathrm{~S} / \mathrm{cm}$. Sensor juga dilengkapi dengan sirkuit salinitas yang berfungsi mengirimkan data pada mikrokontroler. Sirkuit salinitas dapat dilihat pada Gambar 3b. Sensor salinitas tipe ini memiliki harga terjangkau dan akurasi yang tinggi sehingga sangat ideal untuk digunakan pada lingkungan air laut [11].

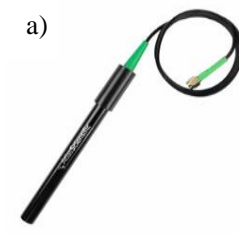

b)

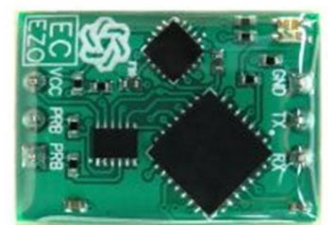

Gambar 3. Sensor dan sirkuit salinitas Atlas-Scientific

\section{Sensor Suhu}

Sensor yang digunakan untuk mengukur suhu adalah DS18B20 seperti disajikan pada Gambar 4. Sensor suhu dihubungkan dengan resistor pada pin input dan tegangan masuk. Sensor ini dikalibrasi pada ruangan terbuka dan mendapatkan nilai yang stabil. Sensor suhu yang digunakan memiliki sensitivitas antara $-55-125{ }^{\circ} \mathrm{C}$.

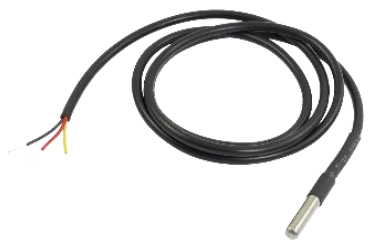

Gambar 4. Sensor suhu DS18B20

Sensor suhu DS18B20 banyak digunakan sebagai perangkat monitoring kualitas air. Sensor jenis ini mudah diperoleh dengan harga terjangkau. Sensor tipe ini dapat bekerja dengan baik untuk mendeteksi perubahan suhu air dari yang rendah hingga tinggi [12] dengan tingkat kesalahan pengukuran suhu $<2 \%$ [13].

\section{Mikrokontroler}

Mikrokontroler adalah suatu rangkaian terintegrasi yang bekerja untuk aplikasi pengendalian. Meskipun mempunyai bentuk lebih kecil dari komputer pribadi, mikrokontroler dibangun dengan elemen-elemen yang sama sehingga dapat berfungsi layaknya komputer [14]. Arduino mega 2560 merupakan papan mikrokontroler 
berdasarkan datasheet ATmega2560 yang diprogram menggunakan software arduino dan dapat berjalan baik secara online maupun offline [15]. Sistem monitoring kualitas air laut dibuat menggunakan mikrokontrol arduino mega 2560 seperti disajikan pada Gambar 5.

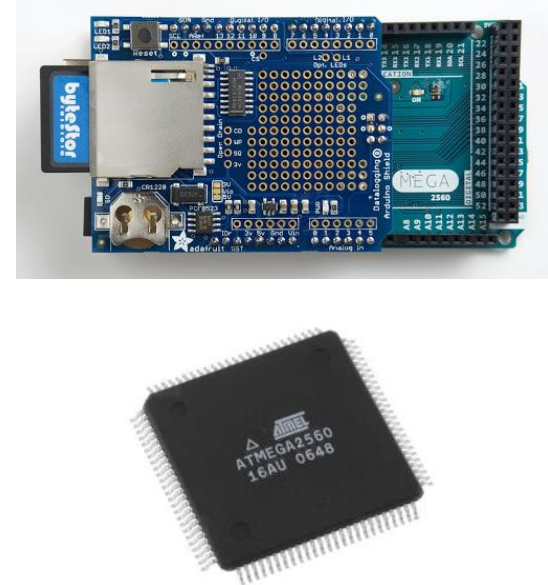

Gambar 5. Arduino mega 2560

\section{E. Algoritma Mikrokontroler}

Untuk menjalankan perangkat keras diperlukan perangkat lunak sebagai penggerak sistem. Pada penelitian ini, dikembangkan alogritma mikrokontroler arduino mega 2560 dengan bahasa C. Bahasa C merupakan bahasa yang dapat digunakan untuk pembuatan sistem operasi, pengolah gambar dan pembuatan kompilator bahasa pemrograman baru sehingga banyak digunakan pada pembuatan sistem monitoring dengan mikrokontrol [16], [17]. Diagram alir algoritma yang dikembangkan disajikan pada Gambar 5.

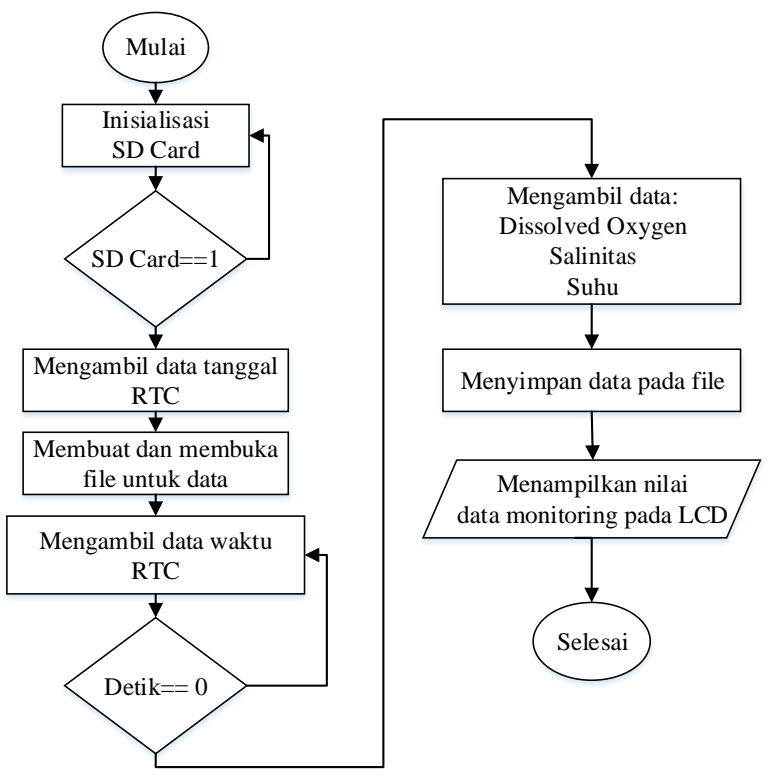

Gambar 5. Algoritma mikrokontroler Arduino Mega 2560

\section{F. Rangkaian Output}

Data hasil monitoring dapat dilihat langsung melalui layar liquid crystal display (LCD). LCD adalah suatu jenis media tampilan yang menggunakan kristal cair sebagai penampil utama [18]. LCD merupakan komponen elektronika yang berfungsi sebagai tampilan sebuah data, baik karakter, huruf ataupun grafik [19], [20]. Selain dapat dilihat langsung Selain dapat dilihat langsung melalui LCD, hasil monitoring juga disimpan pada SD card melalui perekam data (logger). Perekam data merupakan suatu perangkat elektronik yang berfungsi mencatat/ merekam data dari waktu ke waktu secara kontinu dan dapat disimpan dengan baik menggunakan media penyimpanan SD-card [21], [22]. Media penyimpanan SD-card lebih efisien dalam menyimpan data hasil pengukuran sensor yang dipasang pada mikrokontrol [23]. Rancangan sistem output dan tampilan LCD disajikan pada Gambar 6 dan Gambar 7.

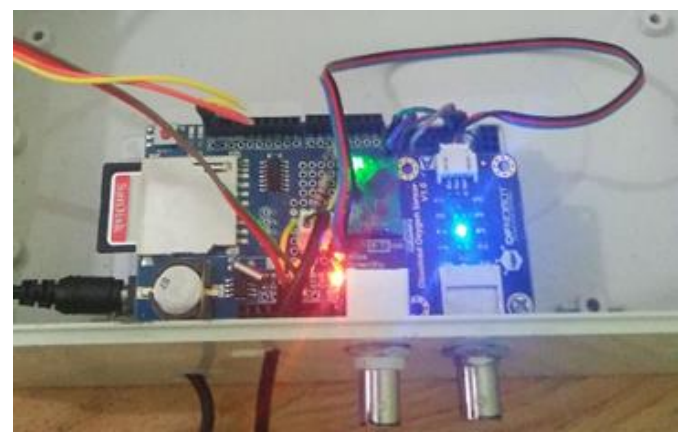

Gambar 6. Rangkaian output sistem monitoring kualitas air

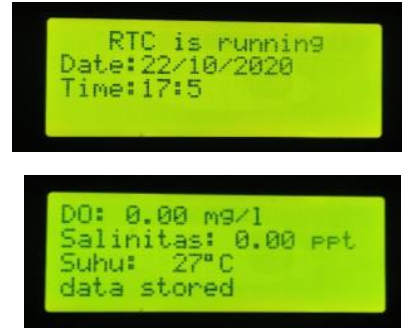

(a)

(b)

Gambar 7. Tampilan LCD untuk (a) real time clock dan (b) data hasil monitoring sensor yang terhubung

Rangkain sistem monitoring kualitas air membutuhkan tegangan yang relatif rendah $(9 \mathrm{~V})$ sehingga dapat disuplai dari berbagai sumber misalnya generator, aliran listrik PLN atau sumber energi lainnya. Pada penerapannya energi terbarukan seperti perangkat panel surya atau kincir angin dapat digunakan sebagai sumber energi untuk menjalankan sistem monitoring kualitas air berbasis arduino [24].

\section{HASIL DAN PEMBAHASAN}

Perangkat sensor yang telah terhubung dengan sistem monitoring harus dilakukan kalibrasi sehingga nilai parameter yang diperoleh sesuai dengan kondisi yang 
sebenarnya. Setelah semua sensor berhasil dikalibrasi, maka dilakukan pengujian dengan kondisi air yang berbeda. Pengujian bertujuan untuk menentukan kemampuan sistem yang dibuat dalam menampilkan data hasil pengukuran sesuai dengan jenis sensor yang digunakan [25].

\section{A. Kalibrasi Sensor}

Sensor DO dikalibrasi menggunakan cara single point calibration dengan mencelupkan probe sensor DO kedalam cairan kalibrasi. Pada proses ini sensor dicelupkan pada cairan kallibrasi $0 \mathrm{mg} / \mathrm{l}$ (Gambar 8). Kalibrasi ini dilakukan dengan mengirimkan perintah kata "calibration" pada mikrokontroler dalam waktu 15 menit sehingga nilai yang dibaca oleh sensor stabil. Jika nilai telah stabil, maka tindakan selanjutnya adalah mengirimkan perintah "satcal" sehingga kalibrasi telah selesai. Proses kalibrasi diakhiri dengan mengirim perintah "exit".

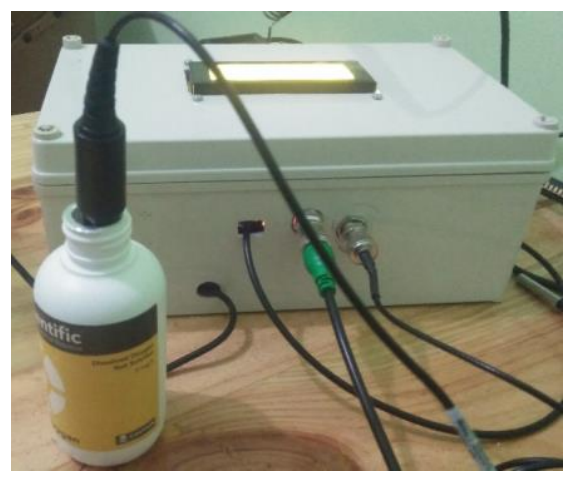

Gambar 8. Kalibrasi sensor DO

Proses kalibrasi sensor salinitas dilakukan dengan dua cara yaitu dry calibration dan two point calibration. Dry calibration dilakukan dengan cara membiarkan sensor salinitas menangkap nilai pada ruangan terbuka sebesar 0 $\mathrm{mS}$. Proses ini dilakukan selama 15 menit agar mendapatkan nilai yang stabil. Setelah nilai stabil sebesar $0 \mathrm{mS}$ didapatkan, maka dikirimkan perintah" "Cal,dry" hingga diperoleh respon benar dari sistem. Selanjutnya dilakukan two points calibration dengan mencelupkan sensor salinitas pada dua cairan test solution sebesar $12,880 \mathrm{mS}$ (low point) dan 150,000 mS (high points) seperti disajikan pada Gambar 9. Jika sensor menangkap nilai sesuai dengan jenis cairan tersebut maka kalibrasi berhasil dilakukan dan diakhiri dengan mengirimkan perintah “cal,low, 12880" dan “cal,high,150000'. Ilustrasi perintah pada saat kalibrasi sensor disajikan pada Gambar 10 .

\section{B. Pengujian Sensor}

Proses pengujian sensor suhu, DO dan salinitas dilakukan pada wadah pengujian dengan volume air 1 liter. Pengujian dilakukan selama 25 menit yang dibagi dalam tiga tahapan. Pengujian tahap pertama dilakukan dengan mencelupkan ketiga sensor dalam air tawar bersuhu hangat yang telah disiapkan dan didiamkan selama delapan menit sehingga diperoleh data pengukuran yang tersimpan dalam SD-card. Setelah delapan menit, tambahkan garam halus sebanyak $10 \mathrm{~g}$ sambil diaduk perlahan hingga semua garam terlarut dan diamkan hingga delapan menit berikutnya. Perubahan suhu, DO dan salinitas selama akan tercatat pada SD-card. Selanjutnya, tambahkan kembali $10 \mathrm{~g}$ garam halus dan aduk hingga semua garam terlarut. Penambahan garam akan meningkatkan salinitas yang akan terbaca oleh sensor salinitas.

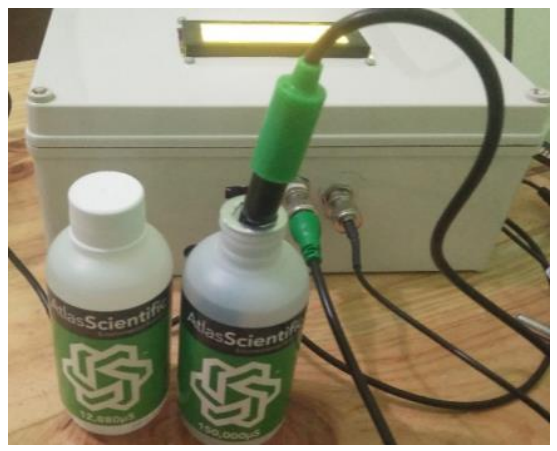

Gambar 9. Kalibrasi sensor salinitas

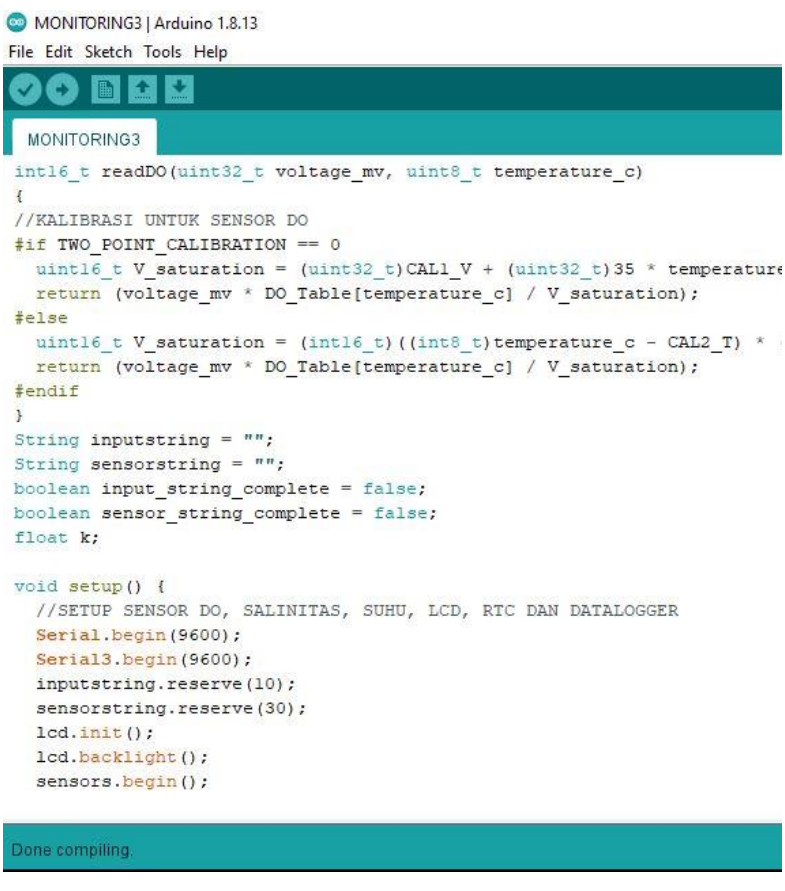

Gambar 10. Ilustrasi perintah kalibrasi sensor

Hasil pengujian menunjukkan bahwa sensor suhu dapat bekerja dengan baik. Suhu air pada awal pengujian adalah $30^{\circ} \mathrm{C}$ dan semakin rendah seiring lamanya pengujian dilakukan. Suhu air setelah pengujian selama 25 menit turun menjadi $28^{\circ} \mathrm{C}$ seperti disajikan pada Gambar 11 .

Sensor DO yang digunakan juga dapat berfungsi dengan baik selama proses pengujian. Pada kondisi awal, nilai DO yang terbaca stabil dengan nilai sebesar 2,70 $\mathrm{mg} / \mathrm{l}$. Pada saat penambahan garam halus dan dilakukan proses pengadukan, maka nilai DO meningkat drastis hingga 5,47 mg/l. Namun demikian, nilai DO kembali 
menurun seiring dengan lamanya proses pengujian. Nilai DO kembali meningkat ketika dilakukan pengadukan kedua seperti disajikan pada Gambar 12. Pengadukan menyebabkan jumlah oksigen di air bertambah karena adanya interaksi antara oksigen di udara dengan permukaan air. Semakin lama dan semakin kuat proses pengadukan yang dilakukan maka kandungan DO di air akan semakin meningkat [26].

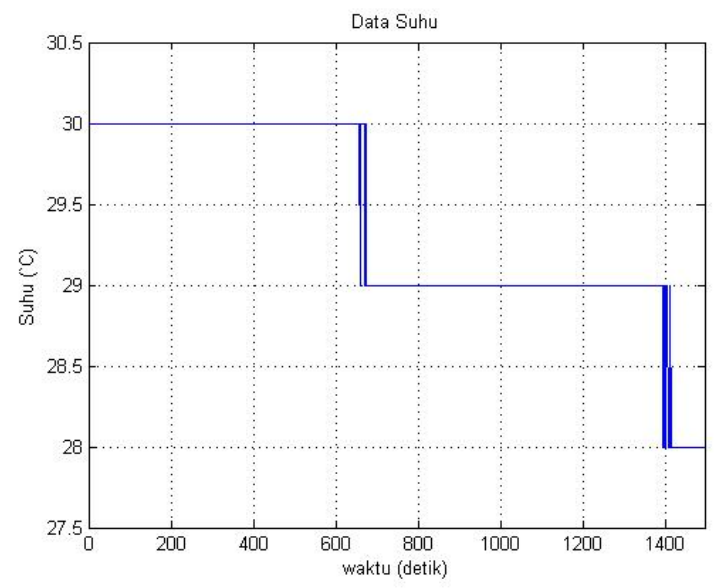

Gambar 11. Hasil pengujian sensor suhu

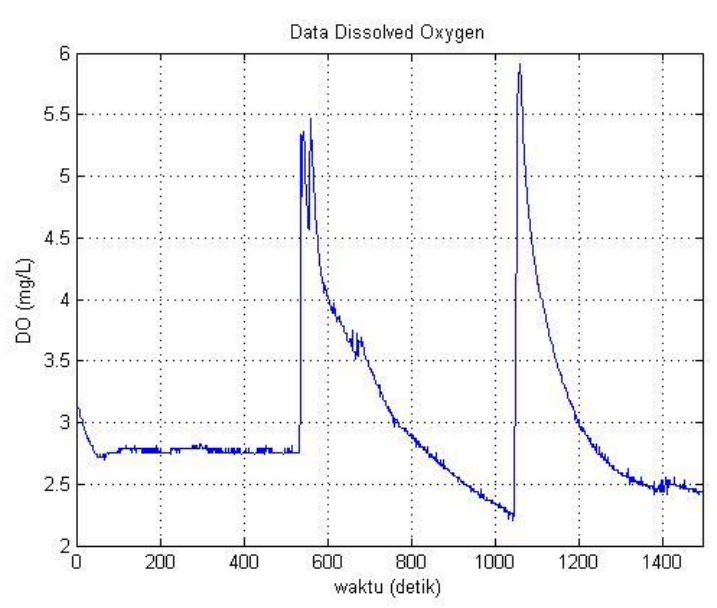

Gambar 12. Hasil pengujian sensor DO

Pengujian sensor salinitas menunjukkan fungsi yang baik. Pada pengukuran air tawar sensor menunjukkan salinitas 0 ppt karena tidak ada kandungan garam terlarut di dalamnya. Penambahan garam sebanyak 10 gram meningkatkan rata-rata kadar salinitas yang terukur oleh sensor menjadi 9,20 ppt. Kadar salinitas meningkat drastis dengan penambahan 10 gram garam berikutnya menjadi 20,52 ppt seperti disajikan pada Gambar 13 .

Data yang terbaca oleh sensor berhasil terekam dengan baik pada SD-card melalui perekam data yang digunakan. Selain itu, data hasil pengukuran juga dapat dilihat langsung pada layar yang digunakan seperti disajikan pada Gambar 14. Berdasarkan hasil pengujian, maka sistem monitoring kualitas air laut yang dibangun dapat digunakan pada lingkungan yang sesungguhnya.

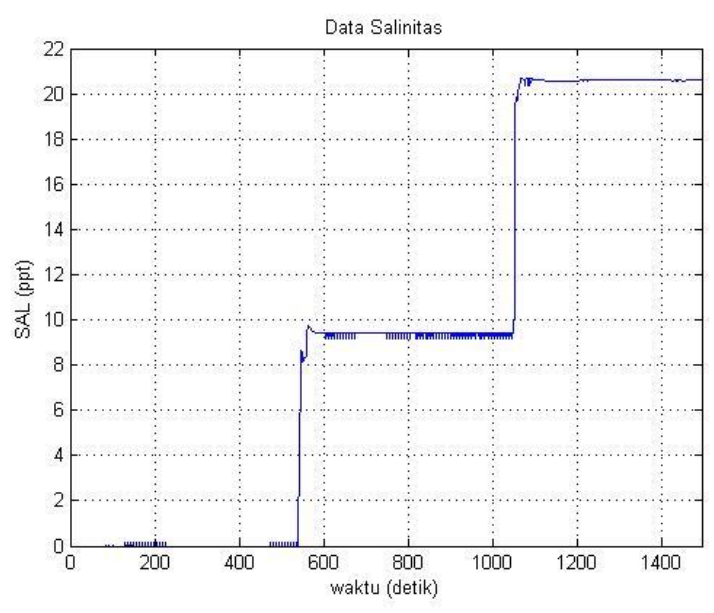

Gambar 13. Hasil pengujian sensor salinitas

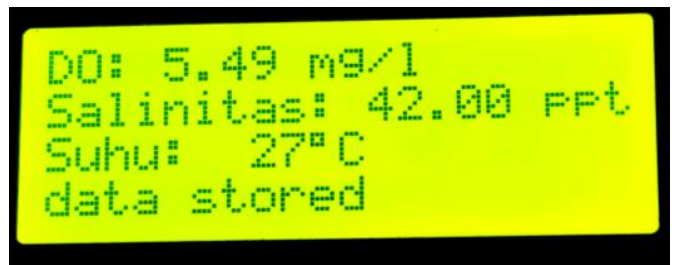

Gambar 14. Layar display hasil pengukuran

Hasil pengujian menunjukkan bahwa sistem monitoring yang dihasilkan dapat berfungsi dengan baik sesuai dengan parameter sensor yang digunakan. Adanya perubahan parameter yang mempengaruhi jumlah DO berupa pengadukan dapat dibaca dengan baik oleh sistem. Selain itu, penambahan garam juga dapat dibaca dengan baik oleh sensor dengan menunjukkan adanya peningkatan nilai salinitas. Sistem kendali berbasis arduino merupakan perangkat kontrol yang sederhana dan terjangkau yang dapat digunakan untuk berbagai kebutuhan antara lain monitoring kualitas air karamba ikan air tawar [8], tambak udang vamame [9] maupun tambak bandeng [25].

Kinerja sistem monitoring hasil rancangan telah divalidasi. Hasil validasi menunjukkan bahwa perbedaan hasil pengukuran dengan alat standar relatif kecil. Parameter DO memiliki nilai perbedaan rata-rata sebesar $3,8 \%$, suhu sebesar $3,7 \%$ dan salinitas sebesar $0,8 \%$ seperti disajikan pada Tabel 1. Berdasarkan hasil tersebut maka sistem monitoring yang kembangkan memiliki kinerja dan akurasi yang baik dengan tingkat kesalahan antara $0,8-3,8 \%$.

Pada penerapannya, sumber energi sistem monitoring dapat berasal dari aliran listrik PLN, generator atau menggunakan sumber energi terbarukan. Kebutuhan energinya yang rendah menjadikan alternatif sumber energinya sangat beragam. Lokasi budidaya organisme laut yang umumnya di wilayah pesisir atau di laut memungkinkan pemanfaatan energi matahari dan angin sebagai sumber energi sistem monitoring sehingga lebih 
ramah lingkungan. Penggunaan energi matahari telah dilakukan untuk perancangan sistem monitoring kualitas air di tambak udang [24] dan air sungai [27].

TABEL I

VALIDASI KINERJA SMOST DENGAN ALAT STANDAR

\begin{tabular}{lccc}
\hline \multicolumn{1}{c}{ Parameter } & $\begin{array}{c}\text { Alat } \\
\text { Standar }\end{array}$ & $\begin{array}{c}\text { Sistem } \\
\text { monitoring }\end{array}$ & Perbedaan \\
\hline Suhu $\left({ }^{\circ} \mathrm{C}\right)$ & $27,9 \pm 0,09$ & $26,3 \pm 0,19$ & $3,7 \pm 0,08$ \\
Salinitas (ppt) & $40 \pm 1,45$ & $40 \pm 1,35$ & $3,8 \pm 2,41$ \\
Oksigen terlarut & $5,7 \pm 0,09$ & $5,9 \pm 0,08$ & $0,8 \pm 1,34$ \\
$(\mathrm{mg} / \mathrm{l})$ & & & \\
\hline
\end{tabular}

\section{KESIMPULAN}

Sistem monitoring kualitas air dengan mikrokontrol arduino mega 2560 bekerja baik dan dapat menampilkan parameter suhu, DO dan salinitas pada LCD sesuai dengan kondisi yang sesungguhnya dengan tingkat kesalahan antara $0,8-3,8 \%$. Data hasil pengukuran terekam pada SD-card dan dapat dianalisis lebih lanjut untuk berbagai kepentingan.

\section{UCAPAN TERIMA KASIH / ACKNOWLEDGMENT}

Penulis mengucapkan terima kasih kepada lembaga penelitian dan pengabdian kepada masyarakat universitas sultan ageng tirtayasa yang telah memberikan pendanaan untuk pelaksanaan penelitian ini melalui skema penelitian unggulan untirta (PUU).

\section{REFERENSI}

[1] R. Xiao, Y. Wei, D. An, D. Li, X. Ta, Y. Wu, Q. Ren, ”A review on the research status and development trend of equipment in water treatment processes of recirculating aquaculture systems," Reviews in Aquaculture, vol. 11, no. 3, pp. 863-895, August 2019

[2] M. Graham, "The design of an education aquarium", Journal of Biological Curation, vol. 1, no. 5, pp. 1-18, 1999

[3] A. Furukawa, N. Matsuura, M. Mori, M. Kawamata, J. Kusaka, M. Hatamoto, T. Yamaguchi, "Development of a DHS-USB recirculating system to remove nitrogen from a marine fish aquarium", Aquacultural Engineering, vol. 74, pp. 174-179, September 2016

[4] I. R. Mardhiya, A. Surtono, S. W. Suciyati, "Sistem akuisisi data pengukuran kadar oksigen terlarut pada air tambak udang menggunakan sensor dissolved oxygen (DO)," Jurnal Teori dan Aplikasi Fisika, vol. 5, no. 2, pp. 133-140, Juli 2017.

[5] M R.G. Nadi, C. Ruskandi, R.S. Pamungkas, "Desain sistem deteksi kualitas air berbasi multi sensor $\mathrm{pH}$, dissolved oxygen, suhu dan konduktivitas", Journal Online of Physic, vol. 5, no. 1, pp. 48-56, November 2019

[6] Y. H. Kim, N. Lee, B. J. Kim, H. J. Shin, "Realization of IoT based fish farm control using mobile app", Proceeding International Symposium on Computer, Consumer and Control (IS3C), ISBN 978-1-5386-7036-1, pp. 189-192, 2018.

[7] P. Sun and Y. Chen, "Aquaculture remote monitoring system based on internet of things", International Conference on Robots \& Intelligent System (ICRIS), ISBN 978-1-7281-2632-6, pp. $187-$ 190, 2019.

[8] M. E. Pahlawi, E. Kurniawan, Desriyanti, "Rancang bangun sistem monitoring kualitas $\mathrm{pH}$ air keramba ikan berbasis arduino di Telaga Ngebel Kabupaten Ponorogo", Komputek: Jurnal Teknik Universitas Muhammadiyah Ponorogo, vol. 4, no. 1, pp. 110, April 2020

[9] A. E. Multazam, Z. B. Hasanuddin, "Sistem monitoring kualitas air tambak udang vaname", Jurnal IT, vol. 8, no. 2, pp. 118-125, Agustus 2017.
[10] A. R. Lorenzo, A. Y. Dula, N. A. C Valeroso, J. D. C. Munda, B.N.G Supang, V. C. Padilla, G. A. M. Madrigal, T. M. Amado, L. K. S. Tolentino, "Dissolved Oxygen (DO) Meter Hydrological Modelling Using Predictive Algorithms," 2019 IEEE 11th International Conference on Humanoid, Nanotechnology, Information Technology, Communication and Control, Environment, and Management ( HNICEM ), Laoag, Philippines, pp. 1-6, 2019.

[11] L.A. Méndez-Barroso, J.A. Rivas-Márquez, I. Sosa-Tinoco, A. Robles-Morúa, "Design and implementation of a low-cost multiparameter probe to evaluate the temporal variations of water quality conditions on an estuarine lagoon system. Environ Monit Assess., vol. 192, no. 10, 710, Oktober 2020.

[12] M. Imam, E. Apriaskar, Djuniadi, "Pengendalian suhu air menggunakan sensor suhu DS18b20”, Jurnal J-Ensitec, vol. 6, no. 1, pp. 347-352, Desember 2019.

[13] I. A. Rozaq dan N. Yulita., "Uji karakterisasi sensor suhu DS18b20 waterproof berbasis arduino uno sebagai salah satu parameter kualitas air", Prosiding SNATI F K e-4 Tahun 2017. ISBN: 978-602-1180-50-1, pp. 303-309, 2017

[14] S.T. Dewi, R. D. Nyoto, E. D. Marindani, "Perancangan prototipe sistem kontrol suhu dan kelembaban pada gedung walet dengan mikrokontroler berbasis mobile," Jurnal Edukasi dan Penelitian Informatika, vol. 4, no. 1, pp. 36-42, 2018

[15] Siswanto, M. Anif, D. N. Hayati, Yuhefizar, "Pengamanan pintu ruangan menggunakan arduino mega 2560, MQ-2, DHT-11 berbasis android", Jurnal Rekayasa Sistem dan Teknologi Informasi, vol. 3, no. 1, pp. 66-72, April 2019.

[16] A. Wiyono, A. Sudrajat, F. Rahmah, U. Darusalam, "Rancang bangun sistem deteksi dan pengaman kebocoran gas berbasis algoritma bahasa $\mathrm{C}$ dengan menggunakan sensor MQ-6," Komik, vol. 1 , no. 1 , pp. 78-85, Oktober. 2017

[17] I. F. Astuti, A. N. Manoppo, Z. Arifin, "Sistem peringatan din bahaya banjir Kota Samarinda menggunakan sensor ultrasonic berbasis mikrokontroler dengan buzzer dan sms," Jurnal Sebatik, vol. 20, no. 1, pp. 30-34, Juni 2018

[18] H. Yenni dan M. Ridwan, "Implementasi kendali mikrokontroler atmega 8535 pada alat pembuat kopi otomatis", Jurnal Edukasi dan Penelitian Informatika, vol. 1, no. 2, pp. 110-115, Desember 2015

[19] Supandi, Hilda, F. Hadary, "Perancangan sistem data logger pengisian air galon otomatis berbasis mikrokontroler ATMega32", Jurnal Edukasi dan Penelitian Informatika, vol. 3, no. 1, pp. 1-8, Juni 2015

[20] M. S. Mauludin, A. F. Alfalah, D. D. Wibowo, "MQ 2 sebagai sensor anti asap rokok berbasis arduino dan bahasa C", Prosiding SNST ke-7 Tahun 2016, pp. 260-265, 2016.

[21] V. Agti dan S. Suryono, "Sistem pengukuran kekasaran permukaan dinding sumur beton menggunakan ultrasonic ranging dengan media penyimpanan data logiger," Youngster Physics Journal, vol. 5, no. 4, pp. 179-188, Oktober 2016.

[22] J. Sumarsono, B. I. Setiiawan, I. D. M. Subrata, R. S. B. Waspodo, S. K. Saptomo, P. Rejekiningrum, "Rancangan sistem kendali kelembaban tanah berbasis mikrokontroler arduino," Jurnal Keteknikan Pertanian, vol. 7, no. 1, pp. 17-24, April 2019.

[23] Suharjanto, "Rancang bangun otomatisasi intensitas cahaya, suhu dan kelembaban untuk budidaya jamur tiram berbasis mikrokontroler di Desa Kendal, Sekaran, Lamongan," Jurnal Penelitian Teknik Elektro, vol. 2, no. 2, pp. 87-92, September 2017

[24] Y. Y. Maulana, G. Wiranto, D. Kurniawan, "online monitoring kualitas air pada budidaya udang berbasis WSN dan IoT ," Jurnal Inkom, vol. 10, no. 2, pp. 81-86, November 2016.

[25] A. F. Machzar, S. R. Akbar, H. Fitriah, "Implementasi sistem monitoring kualitas air pada budidaya tambak udang dan bandeng", Jurnal Pengembangan Teknologi Informasi dan Ilmu Komputer, vol. 2, no. 1, pp. 3458-3465, Oktober 2018

[26] D. T. Suhendar, A. B. Zaidy, S. I. Sachoemar, "Profil oksigen terlarut, total padatan tersuspensi, amonia, nitrat, fosfat dan suhu pada tambak udang vanamei secara intensif', Jurnal Akuatek, vol. 1, no. 1, pp. 1-11, Juni 2020 
[27] G. Setiaji, "Perancangan sistem pemompaan air sampel tenaga surya untuk sistem online monitoring kualitas air sungai", Jurnal Rekayasa Lingkungan, vol. 10, no. 1, pp. 33-44, Juni 2017. 